\title{
Establishing Winter Origins of Migrating Lesser Snow Geese Using Stable Isotopes
}

\section{Détermination des sites d'hivernage de Petites Oies des neiges en migration au moyen d'isotopes stables}

\author{
Viviane Hénaux $^{1}$, Larkin A. Powell ${ }^{1}$, Mark P. Vrtiska ${ }^{2}$, and Keith A. Hobson ${ }^{3}$
}

\begin{abstract}
Increases in Snow Goose (Chen caerulescens) populations and large-scale habitat changes in North America have contributed to the concentration of migratory waterfowl on fewer wetlands, reducing resource availability, and enhancing risks of disease transmission. Predicting wintering locations of migratory individuals is critical to guide wildlife population management and habitat restoration. We used stable carbon $\left(\delta^{13} \mathrm{C}\right)$, nitrogen $\left(\delta^{15} \mathrm{~N}\right)$, and hydrogen $\left(\delta^{2} \mathrm{H}\right)$ isotope ratios in muscle tissue of wintering Snow Geese to discriminate four major wintering areas, the Playa Lake Region, Texas Gulf Coast, Louisiana Gulf Coast, and Arkansas, and infer the wintering locations of individuals collected later during the 2007 and 2008 spring migrations in the Rainwater Basin (RWB) of Nebraska. We predicted the wintering ground derivation of migrating Snow Geese using a likelihood-based approach. Our three-isotope analysis provided an efficient discrimination of the four wintering areas. The assignment model predicted that 53\% [95\% CI: 37-69] of our sample of Snow Geese from the RWB in 2007 had most likely originated in Louisiana, 38\% [23-54] had wintered on Texas Gulf Coast, and 9\% [0-20] in Arkansas; the assessment suggested that 89\% [73-100] of our 2008 sample had most likely come from Texas Gulf Coast, 9\% [0-27] from Louisiana Gulf Coast, and $2 \%$ [0-9] from Arkansas. Further segregation of wintering grounds and additional sampling of spring migrating Snow Geese would refine overall assignment and help explain interannual variations in migratory connectivity. The ability to distinguish origins of northbound geese can support the development of spatially-adaptive management strategies for the midcontinent Snow Goose population. Establishing migratory connectivity using isotope assignment techniques can be extended to other waterfowl species to determine critical habitat, evaluate population energy requirements, and inform waterfowl conservation and management strategies.
\end{abstract}

RÉSUMÉ. L'accroissement des populations d'Oies des neiges (Chen caerulescens) et les changements d'habitat à grande échelle en Amérique du Nord ont contribué à la concentration de la sauvagine migratrice sur des milieux humides de moins en moins nombreux, à la diminution de la disponibilité des ressources alimentaires et à l'augmentation du risque de transmission de maladies. La capacité à prévoir les sites d'hivernage d'individus migrateurs est essentielle pour orienter la gestion des populations fauniques et la restauration d'habitat. Nous avons utilisé des ratios d'isotopes stables de carbone $(\delta 13 \mathrm{C})$, d'azote $(\delta 15 \mathrm{~N})$ et d'hydrogène $(\delta 2 \mathrm{H})$ dans les tissus musculaires d'Oies des neiges en hiver afin de différencier quatre aires d'hivernage importantes - la région de Playa Lake au Texas, la côte du golfe au Texas, la côte du golfe en Louisiane et l'Arkansas - et de prévoir les sites d'hivernage d'individus récoltés durant la migration printanière de 2007 et celle de 2008 dans la région de Rainwater Basin (RWB) au Nebraska. Nous avons calculé la prévision des sites d'hivernage des Oies des neiges migratrices à l'aide d'une approche fondée sur la vraisemblance. Notre analyse des trois isotopes a permis de différencier efficacement les quatre aires d'hivernage. Le modèle d'attribution a prévu que $53 \%$ [95 \% IC : 37-69] de notre échantillon d'oies de RWB en 2007 provenait fort probablement de la Louisiane, $38 \%$ [23-54] avait hiverné sur la côte du golfe au Texas et 9\% [0-20] en Arkansas; l'attribution a montré que $89 \%$ [73-100] de notre échantillon en 2008 provenait fort probablement de la côte du golfe au Texas, $9 \%$ [0-27] de la côte du golfe en Louisiane et $2 \%$ [0-9] de l'Arkansas. Une division plus fine des aires d'hivernage et davantage d'échantillons d'oies en migration printanière permettraient d'améliorer l'attribution dans l'ensemble et de contribuer à expliquer les variations interannuelles de la connectivité migratoire. La capacité à distinguer la provenance des oies se dirigeant vers le nord peut contribuer à l'élaboration de stratégies de gestion évolutive fondées sur la répartition géographique

\footnotetext{
${ }^{1}$ University of Nebraska-Lincoln, ${ }^{2}$ Nebraska Game and Parks Commission,

${ }^{3}$ Environment Canada
}

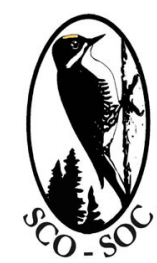

Sponsored by the Society of Canadian Ornithologists and Bird Studies Canada Parrainée par la Société des ornithologistes du Canada et Études d'oiseaux Canada

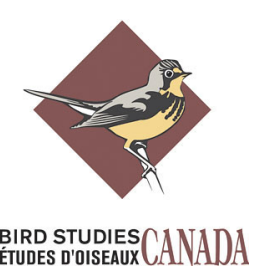


de la population d'Oie des neiges du milieu du continent. L'établissement de la connectivité migratoire au moyen de techniques d'attribution isotopique peut être appliqué à d'autres espèces de sauvagine afin de déterminer l'habitat essentiel, d'évaluer les besoins énergétiques des populations, et d'appuyer les efforts de conservation et les stratégies de gestion de la sauvagine.

Key Words: carbon-13, Chen caerulescens, hydrogen-2, migratory connectivity, nitrogen-15, Rainwater Basin, Snow Goose, spring migration, stable isotope

\section{INTRODUCTION}

Establishing wintering areas of northbound or breeding and natal areas of southbound individuals allows insight into processes affecting various stages of the life cycle of populations of migratory birds. For example, the extent to which environmental conditions on wintering grounds drive spring migration timing and affect individual life cycles is essential in understanding major variations in population dynamics related to overwinter survival (Saino et al. 2004). The strength of the connections between breeding, winter, and stopover habitats can influence the ability of migratory populations to evolve and adapt to selective pressures induced by global changes (review in Webster et al. 2002, Webster and Marra 2005). In addition, continental management of target species requires connections be made between wintering habitats and critical stopover locations used as part of their annual life cycle. Indeed, a good knowledge of migratory connectivity is critical for designing conservation strategies (Martin et al. 2007), implementing adaptive harvest of game populations (Hobson et al. 2009), and predicting potential infectious disease spread in wildlife (Prosser et al. 2009, Gunnarsson et al. 2012).

Snow Goose (Chen caerulescens) management requires spatial derivation of migratory populations. North American Snow Goose populations have dramatically increased over the last decades, causing serious ecological and economic problems (Ankney 1996, Jefferies et al. 2004a, Abraham et al. 2005). The rapid growth in Snow Goose populations has also resulted in an extension of the species' wintering range. Originally dependent on the salt and brackish marshes of the Gulf of Mexico, Snow Geese of the midcontinent population first extended their range to irrigated rice prairies of Texas and Louisiana and now also feed on agricultural crops farther north (Alisauskas and Hobson 1993, Abraham et al. 2005). Studying migratory origins of Snow Geese would also provide information needed for habitat management. Landscape changes in North America have affected the number of wetlands available to spring migrants (Dahl 1990). In Nebraska's Rainwater Basin (RWB) region, more than $85 \%$ of historical wetlands have been converted to agriculture (Smith 1998). Wetland habitat is particularly critical during spring because the RWB is a key stopover site for millions of migratory ducks, geese, shorebirds, and cranes (Bishop and Vrtiska 2008). Migrant waterbirds stop in the RWB for short periods to acquire the nutrient reserves necessary for migration further north and reproduction. Loss of wetlands has resulted in higher concentrations of wintering and migrant waterbird populations, which reduces the availability of food resources and enhances the risk of transmission and spread of infectious diseases (Friend 1992).

Stable isotope analyses of specific animal tissues are now widely used to infer diet, geographical origin, and migratory connectivity (Hobson 1999, Webster et al. 2002, Hobson and Wassenaar 2008, Inger and Bearhop 2008). In contrast to genetic or extrinsic markers, e.g., individual tags or remotesensing devices, this method offers the advantage of not requiring recapture of individuals and may provide reliable information on migratory pathways in species with regional to continental distribution (Rubenstein and Hobson 2004, Hebert and Wassenaar 2005, Hobson and Norris 2008). This approach relies on the fact that food web isotopic signatures are reflected in the tissues of individuals and that such signatures can vary spatially based on a variety of biogeochemical processes (Hobson 2008). Consequently, organisms moving between isotopically distinct food webs can carry with them information on the location of previous feeding. Importantly, this technique is not biased to the distribution of any initially marked populations, in contrast to exogenous marker methods that require marking birds in several wintering regions and then recapturing those that happened to go to the RWB.

Assessments of movements have largely been aimed at southward migration, because most migratory birds in North America conveniently molt flight feathers after breeding and before migration (Hobson and Wassenaar 1997). Gathering information on northward migration, however, demands the use of different tissues. Determining winter origins of spring migratory birds involves three steps (Rubenstein and Hobson 2004, Hobson 2011): (1) choosing an appropriate tissue representing the period of integration appropriate to the time spent on the wintering grounds, (2) isotopically characterizing and differentiating among wintering populations of interest, and (3) inferring geographical wintering locations based on isotopic similarity in tissues of wintering and migrating individuals.

Previous studies using hydrogen $\left(\delta^{2} \mathrm{H}\right)$ measurements of animal keratin-based tissues $\left(\delta^{2} \mathrm{H}_{t}\right)$ to characterize terrestrial source areas have used continent-wide, amount-weighted, growing-season $\delta^{2} \mathrm{H}$ values in precipitation $\left(\delta^{2} \mathrm{H}_{\mathrm{p}}\right)$ and a knowledge of the calibration relationship between $\delta^{2} \mathrm{H}_{\mathrm{p}}$ and $\delta^{2} \mathrm{H}_{\mathrm{t}}$ (reviewed by Hobson 2008, Hobson et al. 2012). 
Table 1. Sampling dates, number of adult Snow Geese (Chen caerulescens) collected, and mean $( \pm \mathrm{SE})$ stable hydrogen $\left(\delta^{2} \mathrm{H}\right)$, carbon $\left(\delta^{13} \mathrm{C}\right)$, and nitrogen $\left(\delta^{15} \mathrm{~N}\right)$ isotope signatures in four major wintering areas of the central flyway and in Nebraska's Rainwater Basin (RWB) during spring migrations 2007 and 2008.

\begin{tabular}{|c|c|c|c|c|}
\hline Sampling places & Sampling dates ( $n=$ number of individuals) & $\delta^{2} \mathrm{H}(\% \circ)$ & $\delta^{13} \mathrm{C}(\% \circ)$ & $\delta^{15} \mathrm{~N}(\% o)$ \\
\hline Playa Lake Region & $13 \operatorname{Dec} 2006(n=5)$ & $-170.3 \pm 3.9$ & $-20.3 \pm 0.2$ & $7.0 \pm 0.2$ \\
\hline Texas Coast & 28 Jan - 2 Mar $2007(n=10) ; 18$ Jan - 11 Feb $2008(n=17)$ & $-118.1 \pm 1.7$ & $-19.9 \pm 0.5$ & $8.0 \pm 0.1$ \\
\hline Louisiana Coast & 19 Feb $2007(n=6) ; 5$ Feb $2008(n=8)$ & $-130.7 \pm 1.2$ & $-22.8 \pm 0.3$ & $7.6 \pm 0.2$ \\
\hline Arkansas & $12 \mathrm{Feb} 2007(n=9)$ & $-144.7 \pm 2.1$ & $-23.1 \pm 0.6$ & $7.0 \pm 0.1$ \\
\hline Nebraska RWB & $27 \mathrm{Feb}-20 \mathrm{Mar} 2007(n=35) ; 7-12 \operatorname{Mar} 2008(n=11)$ & $\mathrm{n} / \mathrm{a}$ & $\mathrm{n} / \mathrm{a}$ & $\mathrm{n} / \mathrm{a}$ \\
\hline
\end{tabular}

$\mathrm{n} / \mathrm{a}=$ not applicable

However, isoscapes for other elements such as carbon $\left(\delta^{13} \mathrm{C}\right)$ and nitrogen $\left(\delta^{15} \mathrm{~N}\right)$ can be more complex because they result from differences in plant photosynthetic pathway $\left(\mathrm{C}_{3}\right.$ vs. $\mathrm{C}_{4}$, CAM plants), water-use efficiency mechanisms, nitrogen fixation process, soil moisture conditions, and human activities, i.e., irrigation, pollution, and land use practices (see papers in Michener and Lajtha 2007). Constructing local, finescale isoscapes from measurements of multiple stable isotope values in prey tissues has been shown to be valuable to determine migration corridors of large carnivores (Hénaux et al. 2011). However, for generalist species, like Snow Geese, the ideal approach involves measuring stable isotope ratios in the tissues of interest (e.g., Yerkes et al. 2008). Accordingly, we documented isotopic differences among four major wintering areas of Snow Geese by measuring $\delta^{13} \mathrm{C}, \delta^{15} \mathrm{~N}$, and $\delta^{2} \mathrm{H}$ in muscle tissues of wintering geese and subsequently predicted the wintering origin of spring migrants using a likelihood-based inference approach.

\section{METHODS}

\section{Tissue selection and collection}

In contrast to studies that inferred breeding origin of migratory individuals from isotopic values in feather tissue grown after breeding, we relied on metabolically active tissue to determine the wintering grounds of lesser Snow Geese that stop in the RWB of Nebraska during spring migration. With a turnover half-life of the order of two weeks for large-bodied geese (see Discussion), we assumed that the muscle tissue of a goose recently arrived at the RWB should reflect the isotopic composition of the diet consumed at its wintering place, i.e., a dietary integration of two to three half-lives.

Snow geese migrating through the Mississippi and Central flyways winter in several distinct areas in the Playa Lake Region, central Mexico, the Gulf coast from Mexico to Louisiana, and along the Mississippi Alluvial Valley (Drewien et al. 2003, Jefferies et al. 2004b, Ridgely et al. 2007). We obtained wings from apparently healthy Snow Geese from hunter-shot birds or collected by shotgun during the winters 2006/2007 and 2007/2008 at four major wintering locations: Playa Lake Region ([PLR] Parmer County, Texas), Texas Gulf
Coast ([TX Coast] Kleberg County, Texas), Louisiana Gulf Coast ([LA Coast] Cameron and Vermilion Parishes, Louisiana), and eastern Arkansas ([AR] Arkansas County, Arkansas; Fig. 1). We also collected wings from hunter-shot or collected Snow Geese at multiple sites in the RWB in February-March 2007 and 2008 (Table 1). One wing from each individual was frozen separately for storage.

Fig. 1. Location of the collection sites of midcontinent Snow Geese (Chen caerulescens) in the Playa Lake Region (PLR), Texas Coast (TX Coast), Louisiana (LA Coast), and Arkansas (AR), and in the Rainwater Basin of Nebraska (RWB) in 2007 and 2008. The Snow Goose wintering range in Central and Mississippi flyways (grey area) was provided by Ridgely et al. (2007).

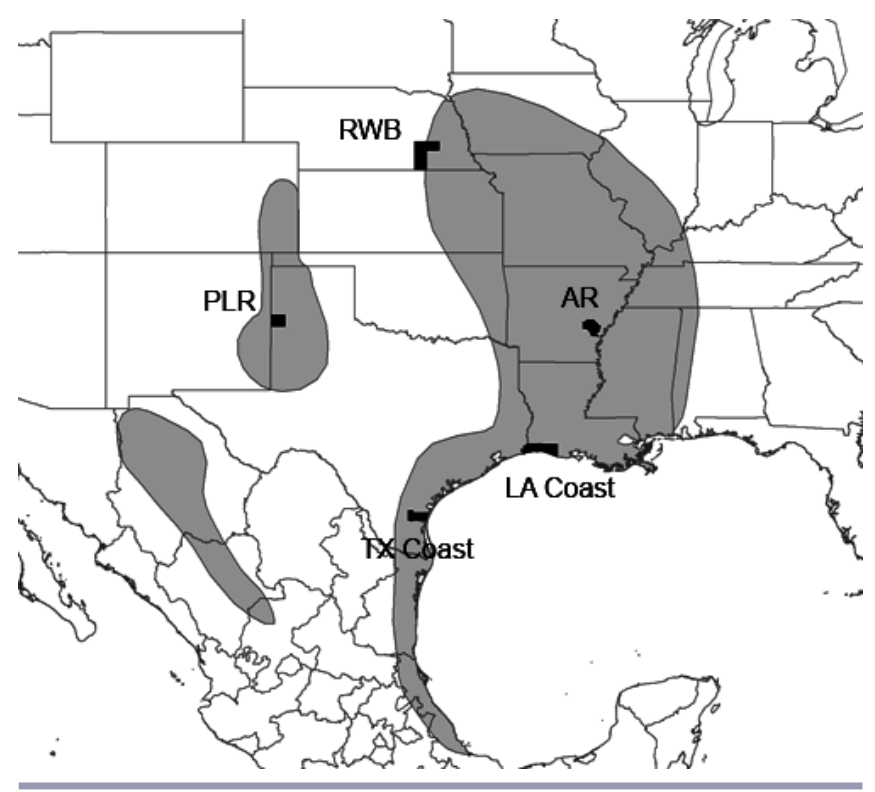

\section{Stable isotope analyses}

Following thawing and dissection of the wing, $1-\mathrm{cm}^{3}$ samples of muscle (bicep) tissue were dried at $60^{\circ} \mathrm{C}$ during $\geq 24$ hours, and ground to powder. Because of the potential influence of lipids on $\delta^{13} \mathrm{C}$ analyses (Post et al. 2007), we removed lipids 
from powdered muscle using a 2:1 chloroform:methanol overnight soaking and rinsed. Stable-hydrogen isotope measurements were performed on $\mathrm{H}_{2}$ derived from hightemperature flash pyrolysis of samples and continuous-flow isotope-ratio mass spectrometry (CF-IRMS). Pure $\mathrm{H}_{2}$ was used as the sample analysis gas and the isotopic reference gas. A Eurovector 3000TM (Eurovector, Milan, Italy) high temperature elemental analyzer (EA) with autosampler was used to automatically pyrolyse muscle samples to a single pulse of $\mathrm{H}_{2}$ gas (and $\mathrm{N}_{2}$ and $\mathrm{CO}$ gas). The resolved $\mathrm{H}_{2}$ sample pulse was then introduced to the isotope ratio mass spectrometer (Micromass IsoprimeTM [Manchester, England] with electrostatic analyzer) via an open split capillary. Repeated analysis of hydrogen isotope intercomparison material IAEA-CH-7, routinely included as a check, yielded an external repeatability of better than $\pm 1.5 \%$. Estimates of the $\delta^{2} \mathrm{H}$ value of the nonexchangeable $\mathrm{H}$ in unknown samples were derived using the comparative equilibration technique of Wassenaar and Hobson (2003, 2006).

For $\delta^{13} \mathrm{C}$ and $\delta^{15} \mathrm{~N}$ measurements, approximately $1 \mathrm{mg}$ of each sample was loaded into tin cups. Our mass spectrometer consisted of a Europa Robo Prep combustion system interfaced with a Europa Tracermat continuous-flow isotoperatio mass spectrometer. Samples were analyzed as five unknowns separated by two in-house albumin standards. Based on within-run standard measurements, we estimate our analytical error to be $\pm 0.1 \%$ for $\delta^{13} \mathrm{C}$ measurements and $\pm 0.3 \%$ o for $\delta^{15} \mathrm{~N}$ measurements. All stable isotope values are expressed in the $\delta$ notation (in units of per mil, \%o). The standards are Vienna Standard Mean Ocean Water - Standard Light Antarctic Precipitation (VSMOW-SLAP) for hydrogen, Pee Dee Belemnite (PDB) standard for carbon, and AIR standard for nitrogen. Stable hydrogen isotope analyses were conducted at the Environment Canada Stable Isotope facility in Saskatoon, Canada. Stable carbon and nitrogen analyses were conducted at the Department of Soil Science Laboratory, University of Saskatchewan, Saskatoon.

\section{Isotopic segregation of wintering areas}

We included only adult-plumaged geese and did not account for sex because we assumed males and females to have identical diet in the same habitat (e.g., Alisauskas et al. 1988). We used mixed-effect models to evaluate difference in isotopic ratio between years in both LA Coast and TX Coast and also between dates (within year) in TX Coast. These analyses indicated no significant random effects (results not shown), so we combined samples collected in 2007 and 2008 for each wintering area.

We conducted a linear discriminant analysis to determine the proportion of individuals from each wintering area whose isotopic signature correctly represented their wintering habitat. We calculated mean stable isotope values in lipidextracted muscle tissues within each wintering region and ran a multiple analysis of variances (MANOVA) to determine whether these areas were segregated isotopically. We conducted these analyses on ranked data (nonparametric test) because data for $\delta^{2} \mathrm{H}$ (Shapiro test: $P=0.002$ ) and $\delta^{13} \mathrm{C}$ values $(P=0.006)$ were not normally distributed. All data were homoscedastic (Levene's test: all $P>0.06$ ). Variations of each isotope among areas were further evaluated using ANOVA (on ranks). We used R 2.11.0 (R Development Core Team 2010) for all statistical analyses.

\section{Stable isotope assignment approach}

We used the likelihood-based assignment method developed by Royle and Rubenstein (2004) to evaluate the likely origin, among the four discrete wintering populations, of each Snow Goose collected in the RWB. The basis of this approach was that we considered all significant wintering areas used by our migrant population sampled and that migrating Snow Geese may be associated with the location most likely to produce the observed tissue isotope values. We defined the expected stable isotope value (for any given isotope $\mathrm{X}$ ) in Snow Goose muscle tissue at each wintering place, $w=1,2, \ldots, W$, as

$$
y_{w, \delta x}=\mu_{w, \delta x} \pm \sigma_{w, \delta x}
$$

where $\mu$ and $\sigma$ represent the mean $\delta \mathrm{X}$ value and standard deviation, respectively. We used

$$
y_{\delta x, i}^{*}
$$

to denote the isotopic value measured in the muscle tissue of the goose $i$ collected at RWB. To determine the most likely wintering origin of this individual, we evaluated the likelihood

$$
f\left(y^{*}{ }_{a x, i} \mid \mu_{w, \delta X}, \sigma_{w, \delta X}\right)
$$

defined as the conditional probability of

$$
y^{*}{ }_{\delta x, i}
$$

given that the individual came from the wintering area $w$. In our study, we considered three elements (hydrogen, carbon, and nitrogen), therefore, the likelihood,

$$
\begin{aligned}
& f\left(y_{\delta^{2} H, \delta^{13} C, \delta^{15} \mathrm{~N}}^{*} \mid \mu_{w, \delta^{2} H}, \sigma_{w, \delta^{2} H}, \mu_{w, \delta} \delta^{13} C,\right. \\
& \left.\sigma_{w, \delta} \delta^{13} C, \mu_{w, \delta} 15_{N}, \sigma_{w, \delta} 15_{N}\right)
\end{aligned}
$$


evaluated at each wintering place $w$, was a multivariate normal likelihood with location parameter $\mu$ and variance-covariance matrix $\Sigma$ as follows:

$$
\begin{aligned}
& \mu=\left(\begin{array}{c}
\mu_{\delta^{2} H} \\
\mu_{\delta^{13} C} \\
\mu_{\delta^{15} \mathrm{~N}}
\end{array}\right) \\
& \Sigma=\left(\begin{array}{ccc}
\sigma_{\delta^{2} H}^{2} & \sigma_{\delta^{2} H, \delta^{13} c} & \sigma_{\delta^{2} H, \delta^{1 S_{N}}} \\
\sigma_{\delta^{2} H, \delta^{13} c} & \sigma_{\delta^{13} c}^{2} & \sigma_{\delta^{13} c, \delta^{15} N} \\
\sigma_{\delta^{2} H, \delta^{15} N} & \sigma_{\delta^{13} C, \delta^{15} N} & \sigma_{\delta^{15} N}^{2}
\end{array}\right)
\end{aligned}
$$

The covariance between two isotopes at each wintering place $w$ was calculated, for example between $\delta^{2} \mathrm{H}$ and $\delta^{13} \mathrm{C}$, as:

$$
\sigma_{\delta^{2} H \delta^{13} c}=\rho_{\delta^{2} H, \delta^{13} c} \sigma_{\delta^{2} H} \sigma_{\delta^{13} c}
$$

where

$$
\rho_{\delta}{ }^{2} \mathrm{H} \delta \delta^{13} \mathrm{C}
$$

is the correlation coefficient between $\delta^{2} \mathrm{H}$ and $\delta^{13} \mathrm{C}$.

Following Royle and Rubenstein (2004), we determined the probability that Snow Goose $i$ originated from $w$ as:

$$
\pi_{w i}=\frac{f\left(y_{i}^{*} \mid \mu_{w}, \sigma_{w}\right)}{\sum_{w=1}^{w} f\left(y_{i}^{*} \mid \mu_{w}, \sigma_{w}\right)}
$$

where

$$
f\left(y_{i}^{*} \mid \mu_{w}, \sigma_{w}\right)
$$

denotes the three-isotope likelihood. Lastly, we calculated the most likely wintering areas of Snow Geese migrating via the RWB as:

$$
\bar{\pi}_{\mathrm{w}}=\frac{\sum_{i} \pi_{\mathrm{w}, i}}{\mathrm{n}}
$$

where $n$ is the number of individual geese collected at the RWB. We used bootstrapping with 1000 resamplings to evaluate the $95 \%$ confidence interval. The upper bound for wintering areas that provided any of the geese sampled at the RWB was calculated as:

$$
\bar{\pi}_{w} \text { (upper) }=\frac{-\ln (\alpha) / W}{n}
$$

where $\alpha=0.05$ is the level of significance (adapted from Jovanovic and Levy 1997). We also conducted the likelihood assignment analysis using only one or two isotopes to contrast results with the tri-isotope analysis.

\section{RESULTS}

\section{Isotopic segregation of wintering grounds}

The discriminant analysis misclassified one AR (11\%) and three TX geese $(10 \%)$ in LA, and one LA goose (7\%) in AR. Isotopic values in Snow Goose muscle tissues showed significant variations among the four wintering areas (MANOVA: $\mathrm{F}_{3,54}=14.50, P<0.001$ ). As expected from the continental isoscape and expected deuterium $\left({ }^{2} \mathrm{H}\right)$ enrichment at marine-influenced sites, i.e., brackish marshes, $\delta^{2} \mathrm{H}$ values followed a decreasing southeast-northwest pattern, ranging from $-118.1 \pm 1.7 \%$ (SE) and $-130.7 \pm 1.2 \%$ in TX and LA coastal areas, respectively, to $-144.7 \pm 2.1 \%$ in AR and -170.3 $\pm 3.9 \%$ o the PLR (Fig. 2). All differences in $\delta^{2} \mathrm{H}$ values between wintering areas $\left(\mathrm{F}_{3,54}=46.37, P<0.001\right)$ were significant (Tukey: $P<0.006)$, except between the PLR and AR $(P=$ $0.43)$.

There was a latitudinal gradient in stable carbon isotope distribution with more ${ }^{13} \mathrm{C}$-depleted diet in AR $(-23.1 \pm 0.6 \%$ ) and LA Coast $(-22.8 \pm 0.3 \%$ ) than in TX Coast $(-19.9 \pm 0.5 \%$ ) and PLR (-20.3 $\pm 0.2 \%$; Fig. 2). Our analysis showed divergent $\delta^{13} \mathrm{C}$ values among all sites $\left(\mathrm{F}_{3,54}=10.86, P<0.001\right)$, except between LA Coast and AR $(P=1.00)$ and TX Coast and PLR $(P=0.92$; other combinations: $P<0.012)$.

We found more ${ }^{15} \mathrm{~N}$-enriched muscle tissues on the TX Coast $(8.0 \pm 0.1 \% \circ)$ and LA Coast $(7.6 \pm 0.2 \% \circ)$ than in AR $(7.0$ $\pm 0.1 \%$ ) and PLR $\left(7.0 \pm 0.2 \%\right.$; Fig. 2). Variations in $\delta^{15} \mathrm{~N}$ values among sites were significant $\left(\mathrm{F}_{3,54}=9.01, P<0.001\right)$ between AR and both LA $(P=0.008)$ and TX Coast $(P<$ $0.001)$ as well as between the PLR and both TX Coast $(P=$ $0.008)$ and LA Coast $(P=0.057)$; isotopic signatures were similar in AR and PLR $(P=1.00)$ and TX Coast and LA Coast $(P=0.85)$. This pattern reflected more ${ }^{15} \mathrm{~N}$-enriched muscle 
tissues on the TX Coast $(8.0 \pm 0.1 \%$ ) and LA Coast (7.6 $\pm 0.2 \%$ o than in AR $(7.0 \pm 0.1 \%$ ) and PLR $(7.0 \pm 0.2 \%$; Fig. 2).

Fig. 2. Stable isotopic signatures in muscle tissues of spring migrating Snow Geese (Chen caerulescens) collected in the Rainwater Basin (RWB) of Nebraska and at four potential wintering areas: Playa Lake Region (PLR), Texas Gulf Coast (TX Coast), Louisiana Coast (LA Coast), and Arkansas (AR). Ellipsoids centered on small black dots indicate the mean (and 95\% confidence interval) muscle isotopic pattern in the four wintering areas. Grey dots and black triangles represent the isotopic signatures of RWB Snow Geese collected in 2007 and 2008, respectively.

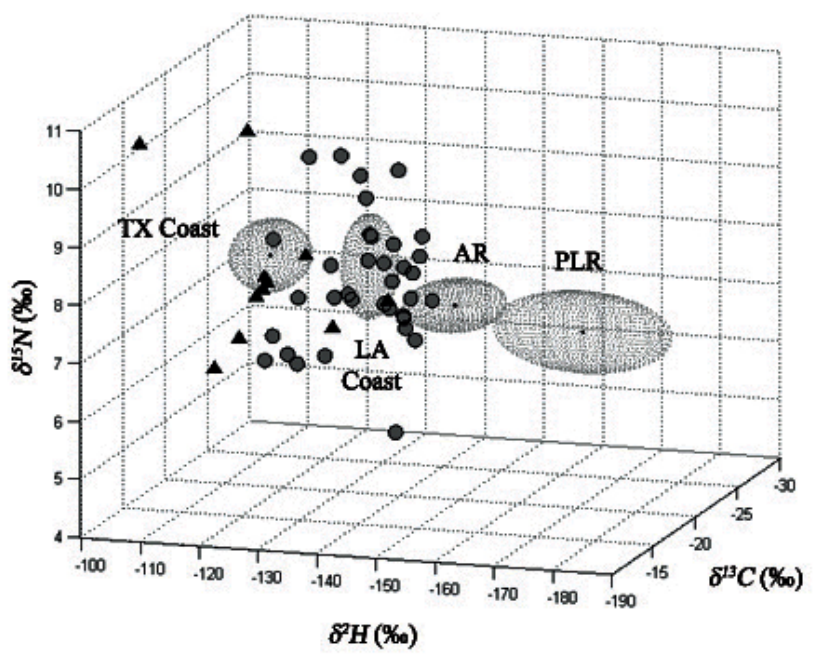

\section{Origin of Snow Geese migrating through the RWB}

The maximum likelihood assignment approach from our triisotope assessment predicted that among the wintering regions considered in our study the LA Coast was the most likely origin for 53\% [95\% CI: 37-69] of the geese collected in the RWB during the 2007 spring migration; the TX Coast was predicted as the origin for $38 \%$ [23-54] and AR was the most likely origin for 9\% [0-20] of the geese in our sample (Fig. 2). The predicted winter distribution of birds differed in 2008 (TX Coast: $89 \%$ [73-100], LA Coast: 9\% [0-27], and AR: $2 \%$ [0-9]). Our tri-isotope assessment predicted that none of the geese collected in 2007 (0\% [0-13]) and 2008 (0\% [0-40]) came from the PLR (Fig. 2). Snow Geese shot in the same Nebraska county came from two or three wintering places.

The assignment analyses based on $\delta^{2} \mathrm{H}$ and $\delta^{13} \mathrm{C}$ or $\delta^{2} \mathrm{H}$ and $\delta^{15} \mathrm{~N}$ provided similar results to the tri-isotope predictions (Fig. 3). The two-isotope analysis with $\delta^{13} \mathrm{C}$ and $\delta^{15} \mathrm{~N}$ predicted increased probabilities of origin from AR and PLR, and reduced probabilities from LA and TX Coast, but the most likely origin remained the same compared to the tri-isotope approach. The single-isotope analyses provided more contrasting inferences.

Fig. 3. Predicted winter origin of spring migrating Snow Geese (Chen caerulescens) collected in Nebraska's Rainwater Basin in springs of 2007 and 2008. Predictions (\%) derived from tri-, dual-, or single-isotope analyses with stable isotopes of hydrogen $(\mathrm{H})$, carbon $(\mathrm{C})$, and nitrogen $(\mathrm{N})$.
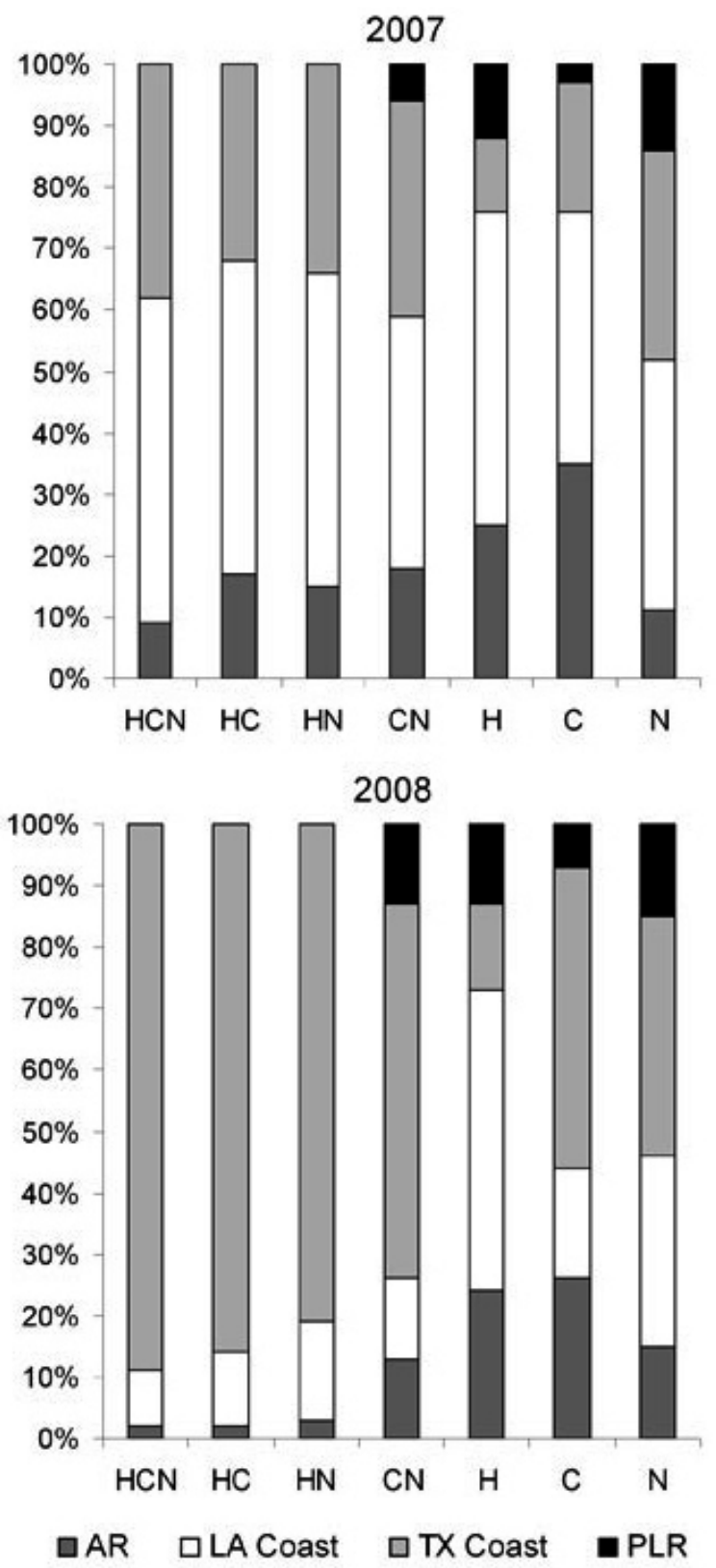


\section{DISCUSSION}

Our study emphasizes the potential of using stable isotope measurements of multiple elements in Snow Geese muscle tissues to establish migratory connectivity between wintering and spring stopover sites. The combination of stable hydrogen, carbon, and nitrogen isotopic ratios from ground-truthed samples provided a marked segregation of four major wintering areas within the Central and Mississippi flyways. Our likelihood-based inference approach predicted that most migrating Snow Geese that we sampled in the RWB wintered along both the LA and TX Coasts in 2007, but primarily on the TX Coast in 2008. We also found that few Snow Geese came from eastern AR or the Mississippi Alluvial Valley (located between LA and AR; Fig. 2) but none from the PLR.

Although no direct experimental information on elemental turnover rates in Snow Goose muscle is available, turnover rate or mean isotopic residence time scales allometrically with body mass (Carleton and Martínez del Rio 2005). Based on body mass and the assumption that muscle turnover rate will be similar to whole blood turnover (see also Haramis et al. 2001), we predicted that isotopic measurements in muscle tissue of Snow Geese easily represented a dietary integration over the previous month. Given that a large number of Snow Geese is present in November in southern Texas (Hobaugh 1984), late October/early November in Arkansas (James and Neal 1986), and early November for the Playa Lake Region (Baar et al. 2008) and southwest Louisiana (Jónsson and Afton 2006), we expect all our wintering birds were in equilibrium with the local diets. After a few-day spring migratory flight, average residency time for waterfowl species in the RWB was estimated, from observation and modeling, to be less than 10 days (Frederikson and Reid 1988, Pearse et al. 2011). Consequently, we are confident that the muscle tissue of the RWB Snow Geese represented their winter habitat and was not affected by the changes in diet and habitat during the early phase of spring migration.

Alisauskas and Hobson (1993) indicated the potential of $\delta^{13} \mathrm{C}$ and $\delta^{15} \mathrm{~N}$ analyses of muscle tissues to characterize winter diets and habitats used by spring staging Snow Geese. In our study, muscle isotopic signatures from $\geq 89 \%$ of the winter-shot geese represented their wintering habitat. Depending on abundance and distribution of crops, Snow Geese in the midcontinent population may consume a large variety of food. The observed spatial variation in Snow Goose $\delta^{13} \mathrm{C}$ values is related to the proportion of $\mathrm{C}_{3}$, e.g., rice, wheat, and $\mathrm{C}_{4}$ plants, e.g., corn, sorghum, in diet (Tieszen et al. 1983), whereas higher $\delta^{15} \mathrm{~N}$ values in muscle tissues of Snow Geese collected in TX coast and LA generally characterized the estuarine/marsh habitat vs. upland environment in AR and TX Playa (Alisauskas and Hobson 1993). We found that $\delta^{2} \mathrm{H}$ values provided an additional discrimination of wintering location, with a typical decreasing southeast-northwest pattern expected from the precipitation isoscape for North America (Hobson 1999,
Bowen et al. 2005). The large variation in muscle $\delta^{2} \mathrm{H}$ values (min: -183 ; max: $-160 \%$ ) and the low number of individuals collected in the PLR may explain that the $\delta^{2} \mathrm{H}$ signature at this site was not significantly different from that in AR. Our triisotope analysis enhanced the characterization and segregation of wintering habitats over the use of only one or two isotopes (Fig. 2), and has been shown to improve the assignment of migrating individuals to a geographic wintering region (Royle and Rubenstein 2004). We note that the higher $\delta^{2} \mathrm{H}(>-115 \%$ o and $\delta^{15} \mathrm{~N}(\geq 10 \%$ ) values in two RWB Snow Geese suggest that these individuals may have wintered in marine-influenced marsh areas located south of the TX coast sampling site, i.e., Mexican Gulf coast. We recommend wildlife managers to collect samples from additional areas, including northern and coastal Mexico, Kansas, and Missouri to get a full coverage of the wintering grounds in the Central and Mississippi flyways (Fig. 1). Snow geese may change diet over winter and also rely on several foraging habitats during short periods depending on resource availability, hunting pressure, and climate conditions (Hobaugh 1984, 1985, Hill and Frederick 1997). Thus, sampling should cover both the natural wetlands and agricultural environments within a specific region, e.g., coastal marshes and rice fields in coastal LA and TX (Bellrose 1980). In addition, given the predicted preferential use of the coastal area by migrating Snow Geese, the use of stable sulfur isotopes $\left(\delta^{34} S\right)$ may be valuable in further discriminating estuarine and marsh habitats from less ${ }^{34} \mathrm{~S}$ enriched terrestrial habitats (Hobson 1999). Monitoring the presence of adventitious color on the head plumage of the geese, which results from feeding in wetlands with deposits of iron oxides, may also provide a good tool to identify Snow Geese that recently used coastal marshes (Alisauskas et al. 1998).

The breeding and wintering range of Snow Geese in North America and links between summer and winter locations had been well established from resighting and recoveries of marked Snow Geese (Cooke et al. 1995, Johnson 1996, Williams et al. 2008). On the other hand, recoveries of spring migrants were too limited to document northward migration with precision, reporting only few recoveries in the RWB (Cooke et al. 1995, Johnson 1996). Ours is the first study to demonstrate the spring migratory connectivity between both LA and TX Coast and the RWB. Although sampling dates and locations in the RWB were similar in both years, our results showed large variations in the potential origins of migrating Snow Geese between springs (Fig. 2). The reasons for this pattern are unclear. We believe our small sample sizes in the RWB may influence overall assignment. Following Thompson (1987), we calculated that a sample size of 510 Snow Geese at the RWB is needed to get predicted assignment probabilities that lie within $\pm 5 \%$ of the true probabilities, and 127 individuals with an error margin of $\pm 10 \%$ (at a significance level $\alpha=0.05$ ). Although snow geese usually exhibit high wintering fidelity (Johnson 1996, Williams et al. 2008), it has 
been suggested that rigorous winter conditions in the Mississippi flyway may alter this pattern. In addition, high spring hunting pressure (e.g., Light Goose Conservation Order) may also influence regional movements (Béchet et al. 2003). Besides, interannual deviations in precipitation $\delta^{2} \mathrm{H}$ patterns (Brewster 2009) can alter $\delta^{2} \mathrm{H}$ isotopic spatial patterns in vegetation and may thus limit the precision of the assignment approach (Wunder and Norris 2008, but see Hobson 2011); the spatial distributions of $\delta^{13} \mathrm{C}$ and $\delta^{15} \mathrm{~N}$ values in food webs are likely less prone to unpredictable betweenyear variations (Bukata and Kyser 2007). We did not detect marked variations in $\delta^{2} \mathrm{H}, \delta^{13} \mathrm{C}$, and $\delta^{15} \mathrm{~N}$ patterns in LA and TX Coast samples between years; yet, interannual deviance can vary spatially and may require year-specific correction algorithms for assignment (Van Wilgenburg et al. 2012). Thus, we also recommend calibration of the isoscapes of wintering areas using known-origin tissues that were the same tissue type and from the same year as the samples from the RWB geese (Hobson et al. 1999, Wunder and Norris 2008). However, if only spring migrating Snow Geese are collected, our findings indicate that applying the dual $\delta^{13} \mathrm{C}$ and $\delta^{15} \mathrm{~N}$ approach with the current isotopic segregation of wintering grounds would not affect overall assignment predictions.

The distribution and abundance of Snow Geese in the RWB is influenced by natural and anthropogenically caused variations in water conditions, hunting pressure (Vrtiska and Sullivan 2009, Webb et al. 2010), and migration chronology, which in many species is related to spring environmental variables, e.g., climatic conditions, food availability (Jonzén et al. 2006, Bridge et al. 2010, Studds and Marra 2011). Additional sampling of birds in the western RWB wetlands is needed to assess spatial distribution of geese in the RWB according to their wintering areas; heterogeneous spatial distribution in the RWB of waterfowl from diverse wintering areas was previously reported (Pearse et al. 2011). Snow Geese populations in the western RWB may be comprised of more birds from the PLR and we fully expect this technique to be able to detect such differences. Expanding our study to additional wintering areas would allow RWB managers to obtain better information of the origin of migrating Snow Geese and adjust the timing of spring harvests to target subpopulations from different wintering areas. Combining origin information with winter census would also provide information on the number of Snow Geese that are expected to use the RWB wetlands each spring, so that adequate food resources and space may be provided. Snow Geese pose a significant threat of an avian cholera outbreak because of its potential role as carrier of the disease bacteria Pasteurella multocida (Samuel et al. 2005). This infectious disease is one of the most important affecting North American waterfowl and has caused tens of thousands of bird deaths in some years in wintering places in the Mississippi and Central flyways (Samuel et al. 2007) and in the RWB (Blanchong et al. 2006).
Therefore, a better understanding of patterns of migratory connectivity may inform decisions made in future years to predict the most likely route of disease spread and prevent disease occurrence and transmission; for example, with preventive habitat management in the RWB or winter culls if infectious pathogens circulate in wintering Snow Goose populations predicted to migrate through the RWB.

Our isotopic approach to delineating population origins of spring migrant Snow Geese at RWB can be easily applied to management and conservation programs in other flyways if unique regional isotopic signatures corresponding to wintering locations can be established. The study of movements between wintering grounds and other spring locations could outline the overall connectivity network of the Snow Goose population. Isotopic analyses of both muscle and feather tissues could delineate spatial connectivity at large scales, with the ability to infer both wintering and breeding origins (e.g., Yerkes et al. 2008). For studies establishing migratory connectivity of endangered species, the use of cellular blood, which exhibits a temporal integration of elements similar to muscle (Hobson and Clark 1993), would be a nondestructive approach to identify previous origins of migratory individuals. Combining isotopic analyses with body condition or diet studies facilitates the detection of key habitats, as in the American Redstart Setophaga ruticilla (Marra et al. 1998), improve our knowledge of waterfowl population requirements, and favor the restoration of critical environments.

Better understanding of the connectivity between breeding, wintering, and migration areas is critical to inform the management strategies of the continental Snow Goose population in North America. Our findings suggest it is possible to discriminate wintering locations of migratory birds at a useful spatial scale within a species' winter range. Our study highlighted the connectivity between LA and TX Gulf Coasts and the eastern part of the RWB. Such assessments show the potential of our methods to inform habitat, harvest, and disease management of Snow Geese and other migratory birds.

Responses to this article can be read online at: http://www.ace-eco.org/vol7/iss1/art5/responses/

\section{Acknowledgments:}

We thank B. Ballard, B. Davis, B. Johnson, L. Naylor, and L. Reynolds for the collection of Snow Geese. B. Mora Alvarez and $M$. Reineke assisted with preparation of samples for isotope analyses. L. Wassenaar performed Hydrogen-2 measurements at the National Water Research Institute in Saskatoon, Canada. Carbon-13 and Nitrogen-15 measurements were performed by M. Stocki at the Department of Soil Science 
Laboratory, University of Saskatchewan, Canada. Data of Snow Goose winter distribution were provided by NatureServe in collaboration with Robert Ridgely, James Zook, The Nature Conservancy - Migratory Bird Program, Conservation International - CABS, World Wildlife Fund - US, and Environment Canada - WILDSPACE. This research was supported by Hatch Act funds through the University of Nebraska Agricultural Research Division, Lincoln, Nebraska to VH and LAP and through an Environment Canada operating grant to KAH. We thank Ryan Norris and two anonymous reviewers for constructive comments and suggestions on an earlier version of this draft

\section{LITERATURE CITED}

Abraham, K. F., R. L. Jefferies, and R. T. Alisauskas. 2005. The dynamics of landscape change and Snow Geese in midcontinent North America. Global Change Biology 11:841-855.

Alisauskas, R. T, C. D. Ankney, and E. E. Klaas. 1988. Winter diets and nutrition of midcontinental Lesser Snow Geese. Journal of Wildlife Management 52:403-414. http://dx.doi.or $\mathrm{g} / 10.2307 / 3801581$

Alisauskas, R. T., and K. A. Hobson. 1993. Determination of Lesser Snow Goose diets and winter distribution using stable isotope analysis. Journal of Wildlife Management 57:49-54. http://dx.doi.org/10.2307/3808999

Alisauskas, R. T., E. E. Klaas, K. A. Hobson, and C. D. Ankney. 1998. Stable-carbon isotopes support use of adventitious color to discern winter origins of Lesser Snow Geese. Journal of Field Ornithology 69:262-268.

Ankney, C. D. 1996. An embarrassment of riches: too many geese. Journal of Wildlife Management 60:217-223. http://dx. doi.org/10.2307/3802219

Béchet, A., J. F. Giroux, G. Gauthier, J. D. Nichols, and J. E. Hines. 2003. Spring hunting changes the regional movements of migrating Greater Snow Geese. Journal of Applied Ecology 40:553-564. http://dx.doi.org/10.1046/j.1365-2664.2003.00812. $\underline{\mathrm{X}}$

Bellrose, F. C. 1980. Ducks, geese and swans of North America. Stackpole Books, Harrisburg, Pennsylvania, USA.

Bishop, A. A., and M. Vrtiska. 2008. Effects of the wetlands reserve program on waterfowl carrying capacity in the Rainwater Basin Region of south-central Nebraska. U.S. Department of Agriculture Natural Resource Conservation Service, Washington, D.C., USA.

Blanchong, J. A., M. D. Samuel, and G. Mack. 2006. Multispecies patterns of avian cholera mortality in Nebraska's rainwater basin. Journal of Wildlife Diseases 42:81-91.
Bowen, G. J., L. I. Wassenaar, and K. A. Hobson. 2005. Application of stable hydrogen and oxygen isotopes to wildlife forensics. Oecologia 143:337-348. http://dx.doi.org/10.1007/ s00442-004-1813-y

Brewster, K. R. 2009. Role of landscape composition and geographical location on breeding philopatry in grassland passerines: a stable isotope approach. Thesis. University of Saskatchewan, Saskatoon, Saskatchewan, Canada.

Bridge, E. S., J. F. Kelly, P. E. Bjornen, C. M. Curry, P. H. C. Crawford, and J. M. Paritte. 2010. Effects of nutritional condition on spring migration: do migrants use resource availability to keep pace with a changing world? Journal of Experimental Biology 213:2424-2429. http://dx.doi.org/10.12 42/jeb.041277

Bukata, A. R., and T. K. Kyser. 2007. Carbon and nitrogen isotope variations in tree-rings as records of perturbations in regional carbon and nitrogen cycles. Environmental Science \& Technology 41:1331-1338. http://dx.doi.org/10.1021/es061 $\underline{414 \mathrm{~g}}$

Baar, L., R. S. Matlack, W. P. Johnson, and R. B. Barron. 2008. Migration chronology of waterfowl in the southern high plains of Texas. Waterbirds 31:394-401. http://dx.doi.org/10. 1675/1524-4695-31.3.394

Carleton, S. A., and C. Martínez del Rio. 2005. The effect of cold-induced increased metabolic rate on the rate of ${ }^{13} \mathrm{C}$ and ${ }^{15} \mathrm{~N}$ incorporation in House Sparrows (Passer domesticus). Oecologia 144:226-232. http://dx.doi.org/10.1007/s00442-00 5-0066-8

Cooke, F., R. F. Rockwell, and D. B. Lank. 1995. The Snow Geese of La Pérouse Bay. Oxford University Press, New York, New York, USA.

Dahl, T. E. 1990. Wetlands losses in the United States 1780's to 1980's. U.S. Fish and Wildlife Service, Washington, D.C., USA.

Drewien, R. C., A. L. Terrazas, J. P. Taylor, J. M. O. Barraza, and R. E. Shea. 2003. Status of Lesser Snow Geese and Ross's Geese wintering in the interior highlands of Mexico. Wildlife Society Bulletin 31:417-432.

Fredrickson, L. H., and F. A. Reid. 1988. Waterfowl use of wetland complexes. U.S. Department of the Interior, Fish and Wildlife Leaflet 13.2.1.

Friend, M. 1992. Environmental influences on major waterfowl diseases. Transactions of the North American Wildife and Natural Resources Conference 57:517-525.

Gunnarsson, G., N. Latorre-Margalef, K. A. Hobson, S. L. Van Wilgenburg, J. Elmberg, B. Olsen, and J. Waldenström. 2012. Disease dynamics and bird migration - linking Mallards Anas platyrhynchos and influenza A virus in time and space. 
PLOS ONE 7(4):e35679. http://dx.doi.org/10.1371/journal.po $\underline{\text { ne. } 0035679}$

Haramis, G. M., D. G. Jorde, S. A. Macko., and J. L. Walker. 2001. Stable-isotope analysis of Canvasback winter diet in upper Chesapeake Bay. Auk 118:1008-1017. http://dx.doi.org /10.1642/0004-8038(2001)118[1008:SIAOCW]2.0.CO;2

Hebert, C. E., and L. I. Wassenaar. 2005. Feather stable isotopes in western North American waterfowl: spatial patterns, underlying factors, and management applications. Wildlife Society Bulletin 33:92-102. http://dx.doi.org/10.2193 /0091-7648(2005)33[92:FSIIWN]2.0.CO;2

Hénaux, V., L. A. Powell, K. A. Hobson, C. K. Nielsen, and M. LaRue. 2011. Tracking large carnivore dispersal using isotopic clues in claws: an application to cougars across the Great Plains. Methods in Ecology and Evolution 2:489-499. http://dx.doi.org/10.1111/j.2041-210X.2011.00107.x

Hill, M. R. J., and R. B. Frederick. 1997. Winter movements and habitat use by Greater Snow Geese. Journal of Wildlife Management 61:1213-1221. http://dx.doi.org/10.2307/3802119

Hobaugh, W. C. 1984. Habitat use by Snow Geese wintering in southeast Texas. Journal of Wildlife Management 48:1085-1096. http://dx.doi.org/10.2307/3801770

Hobaugh, W. C. 1985. Body condition and nutrition of Snow Geese wintering in southeastern Texas. Journal of Wildlife Management 49:1028-1037. http://dx.doi.org/10.2307/3801390

Hobson, K. A. 1999. Tracing origins and migration of wildlife using stable isotopes: a review. Oecologia 120:314-326. http ://dx.doi.org/10.1007/s004420050865

Hobson, K. A. 2008. Applying isotopic methods to tracking animal movements. Pages 45-78 in K. A. Hobson and L. I. Wassenaar, editors. Tracking animal migration using stable isotopes. Elsevier, New York, New York, USA. http://dx.doi. org/10.1016/S1936-7961(07)00003-6

Hobson, K. A. 2011. Isotopic ornithology: a perspective. Journal of Ornithology 152:49-66. http://dx.doi.org/10.1007/ $\underline{\text { s10336-011-0653-X }}$

Hobson, K. A., and R. W. Clark. 1993. Turnover of $\delta^{13} \mathrm{C}$ in cellular and plasma fractions of blood: implications for nondestructive sampling in avian dietary studies. Auk 110:638-641.

Hobson, K. A., H. Lormée, S. L. Van Wilgenburg, L. I. Wassenaar, and J. M. Boutin. 2009. Stable isotopes ( $\delta \mathrm{D})$ delineate the origins and migratory connectivity of harvested animals: the case of European Woodpigeons. Journal of Applied Ecology 46:572-581. http://dx.doi.org/10.1111/j.136 5-2664.2009.01651.x
Hobson, K. A., and D. R. Norris. 2008. Animal migration: a context for using new techniques and approaches. Pages 1-20 in K. A. Hobson and L. I. Wassenaar, editors. Tracking animal migration using stable isotopes. Elsevier, New York, New York, USA. http://dx.doi.org/10.1016/S1936-7961(07)00001-2

Hobson, K. A., and L. I. Wassenaar. 1997. Linking breeding and wintering grounds of neotropical migrant songbirds using stable hydrogen isotopic analysis of feathers. Oecologia 109:142-148. http://dx.doi.org/10.1007/s004420050068

Hobson, K. A., and L. I. Wassenaar. 2008. Tracking animal migration using stable isotopes. Terrestrial Ecology Series, Vol. 2. Elsevier, New York, New York, USA.

Hobson, K. A., L. I. Wassenaar, and O. R. Taylor. 1999. Stable isotopes $\left(\delta \mathrm{D}\right.$ and $\left.\delta^{13} \mathrm{C}\right)$ are geographic indicators of natal origins of monarch butterflies in eastern North America. Oecologia 120:397-404. http://dx.doi.org/10.1007/s004420050872

Hobson, K. A., S. L. Van Wilgenburg, L. I. Wassenaar, and K. Larson. 2012. Linking hydrogen $\left(\delta^{2} \mathrm{H}\right)$ isotopes in feathers and precipitation: sources of variance and consequences for assignment to global isoscapes. PLoS ONE 7(4):e35137. http ://dx.doi.org/10.1371/journal.pone.0035137

Inger, R., and S. Bearhop. 2008. Application of stable isotope analyses to avian ecology. Ibis 150:447-461. http://dx.doi.org /10.1111/j.1474-919X.2008.00839.x

James, D. A., and J. C. Neal 1986. Arkansas birds - their distribution and abundance. The University of Arkansas Press, Fayetteville, Arkansas, USA.

Jefferies, R. L., R. F. Rockwell, and K. F. Abraham. 2004a. Agricultural food subsidies, migratory connectivity and largescale disturbance in arctic coastal systems: a case study. Integrative and Comparative Biology 44:130-139. http://dx.d oi.org/10.1093/icb/44.2.130

Jefferies, R. L., R. F. Rockwell, and K. F. Abraham. $2004 b$. The embarrassment of riches: agricultural food subsidies, high goose numbers, and loss of Arctic wetlands - a continuing saga. Environmental Reviews 11:193-232. http://dx.doi.org/1 $\underline{0.1139 / \mathrm{a} 04-002}$

Johnson, S. R. 1996. Staging and wintering areas of Snow Geese nesting on Howe Island, Alaska. Arctic 49:86-93.

Jónsson, J. E., and A. D. Afton. 2006. Different time and energy budgets of Lesser Snow Geese in rice-prairies and coastal marshes in southwest Louisiana. Waterbirds 29:451-458. http://dx.doi.org/10.1675/1524-4695(2006)29[451: DTAEBO]2.0.CO;2

Jonzén, N., A. Lindén, T. Ergon, E. Knudsen, J. O. Vik, D. Rubolini, D. Piacentini, C. Brinch, F. Spina, L. Karlsson, M. 
Stervander, A. Andersson, J. Waldenström, A. Lehikoinen, E. Edvardsen, R. Solvang, and N. C. Stenseth. 2006. Rapid advance of spring arrival dates in long-distance migratory birds. Science 312:1959-1961. http://dx.doi.org/10.1126/scien ce. 1126119

Jovanovic, B. D., and P. S. Levy. 1997. A look at the rule of three. American Statistician 51:137-139.

Marra, P. P., K. A. Hobson, and R. T. Holmes. 1998. Linking winter and summer events in a migratory bird by using stablecarbon isotopes. Science 282:1884-1886. http://dx.doi.org/10 $.1126 /$ science. 282.5395 .1884

Martin, T., I. Chadès, P. Arcese, P. P. Marra, H. P. Possingham, and D R. Norris. 2007. Optimal conservation of migratory species. PLOS ONE 2(8):e751. http://dx.doi.org/10.1371/journal. pone. 0000751

Michener, R., and K. Lajtha, editors. 2007. Stable isotopes in ecology and environmental science. Second edition. Blackwell, Oxford, UK. http://dx.doi.org/10.1002/9780470691854

Pearse, A. T., G. L. Krapu, R. R. Cox Jr., and B. E. Davis. 2011. Spring-migration ecology of Northern Pintails in southcentral Nebraska. Waterbirds 34:10-18. http://dx.doi.org/10.1 $\underline{675 / 063.034 .0102}$

Post, D. M., C. A. Layman, D. A. Arrington, G. Takimoto, J. Quattrochi, and C. G. Montaña. 2007. Getting to the fat of the matter: models, methods and assumptions for dealing with lipids in stable isotope analyses. Oecologia 152:179-189. htt p://dx.doi.org/10.1007/s00442-006-0630-x

Prosser, D. J., J. Y. Takekawa, S. H. Newman, B. Yan, D. C. Douglas, Y. Hou, Z. Xing, D. I. Zhang, T. Li, Y. Li, D. Zhao, W. M. Perry, and E. C. Palm. 2009. Satellite-marked waterfowl reveal migratory connection between $\mathrm{H} 5 \mathrm{~N} 1$ outbreak areas in China and Mongolia. Ibis 151:568-576. htt p://dx.doi.org/10.1111/j.1474-919X.2009.00932.x

R Development Core Team. 2010. R: A language and environment for statistical computing. R Foundation for Statistical Computing, Vienna, Austria. ISBN 3-900051-07-0. [online] URL: http://www.r-project.org/

Ridgely, R. S., T. F. Allnutt, T. Brooks, D. K. McNicol, D. W. Mehlman, B. E. Young, and J. R. Zook. 2007. Digital distribution maps of the birds of the western hemisphere. Version 3.0. NatureServe, Arlington, Virginia, USA.

Royle, J. A., and D. R. Rubenstein. 2004. The role of species abundance in determining breeding origins of migratory birds with stable isotopes. Ecological Applications 14:1780-1788. http://dx.doi.org/10.1890/04-0175

Rubenstein, D. R., and K. A. Hobson. 2004. From birds to butterflies: animal movement patterns and stable isotopes.
Trends in Ecology \& Evolution 19:256-263. http://dx.doi.org/ 10.1016/j.tree.2004.03.017

Saino, N., T. Szép, R. Ambrosini, M. Romano, and A. P. Møller. 2004. Ecological conditions during winter affect sexual selection and breeding in a migratory bird. Proceedings of the Royal Society B 271:681-686. http://dx.doi.org/10.1098/ rspb.2003.2656

Samuel, M. D., D. J. Shadduck, D. R. Goldberg, and W. P. Johnson. 2005. Avian cholera in waterfowl: the role of Lesser Snow and Ross's Geese as disease carriers in the Playa Lakes Region. Journal of Wildlife Diseases 41:48-57.

Samuel, M. D., R. G. Botzler, G. A. Wobeser. 2007. Avian cholera. Pages 239-269 in N. J. Thomas, D. B. Hunter, and C. T. Atkinson, editors. Infectious diseases of wild birds. Blackwell, Oxford, UK. http://dx.doi.org/10.1002/978047034 4668.ch12

Smith, L. M. 1998. Research needs for the Rainwater Basin of Nebraska: a hierarchical approach. Nebraska Game and Parks Commission, Lincoln, Nebraska, USA.

Studds, C.E., and P. P. Marra. 2011. Rainfall-induced changes in food availability modify the spring departure programme of a migratory bird. Proceedings of the Royal Society B: Biological Sciences 278:3437-3443. http://dx.doi.org/10.1098/ rspb.2011.0332

Thompson, S. K. 1987. Sample size for estimating multinomial proportions. American Statistician 41:42-46.

Tieszen, L. L., T. W. Boutton, K. G. Tesdahl, and N. A. Slade. 1983. Fractionation and turnover of stable carbon isotopes in animal tissues: implications for $\delta^{13} \mathrm{C}$ analysis of diet. Oecologia 57:32-37. http://dx.doi.org/10.1007/BF00379558

Van Wilgenburg, S. L., K. A. Hobson, K. R. Brewster, and J. M. Welker. 2012. Assessing dispersal in threatened migratory birds using stable hydrogen isotope $(\delta \mathrm{D})$ analysis of feathers. Endangered Species Research 16:17-29. http://dx.doi.org/10. 3354/esr00383

Vrtiska, M. P., and S. Sullivan. 2009. Abundance and distribution of Lesser Snow and Ross's Geese in the Rainwater Basin and Central Platte River Valley of Nebraska. Great Plains Research 19:147-155.

Wassenaar, L. I., and K. A. Hobson. 2003. Comparative equilibration and online technique for determination of nonexchangeable hydrogen of keratins for animal migration studies. Isotopes in Environmental and Health Studies 39:211-217. http://dx.doi.org/10.1080/1025601031000096781

Wassenaar, L. I., and K. A. Hobson. 2006. Stable-hydrogen isotope heterogeneity in keratinous materials: mass 
spectrometry and migratory wildlife tissue subsampling strategies. Rapid Communications in Mass Spectrometry 20:2505-2510. http://dx.doi.org/10.1002/rcm.2626

Webb, E. B., L. M. Smith, M. P. Vrtiska, T. G. Lagrange. 2010. Effects of local and landscape variables on wetland bird habitat use during migration through the Rainwater Basin. Journal of Wildlife Management 74:109-119. http://dx.doi.or $\mathrm{g} / 10.2193 / 2008-577$

Webster, M. S., and P. P. Marra. 2005. The importance of understanding migratory connectivity and seasonal interactions. Pages 199-209 in R. Greenberg and P. P. Marra, editors. Birds of two worlds: the ecology and evolution of migration. John Hopkins University Press, Baltimore, Maryland, USA.

Webster, M. S., P. P. Marra, S. M. Haig, S. Bensch, and R. T. Holmes. 2002. Links between worlds: unraveling migratory connectivity. Trends in Ecology \& Evolution 17:76-83. http:// dx.doi.org/10.1016/S0169-5347(01)02380-1

Williams, C. K., M. D. Samuel, V. V. Baranyuk, E. G. Cooch, and D. Kraege. 2008. Winter fidelity and apparent survival of Lesser Snow Goose populations in the Pacific flyway. Journal of Wildlife Management 72:159-167. http://dx.doi.org/10.219 3/2005-748

Wunder, M. B., and D. R. Norris. 2008. Analysis and design for isotope-based studies of migratory animals. Pages 107-128 in K. A. Hobson and L. I. Wassenaar, editors. Tracking animal migration using stable isotopes. Elsevier, New York, New York, USA. http://dx.doi.org/10.1016/S1936-7961(07)00005$\underline{X}$

Yerkes, T., K. A. Hobson, L. I. Wassenaar, R. Macleod, and J. M. Coluccy. 2008. Stable isotopes $\left(\delta \mathrm{D}, \delta^{13} \mathrm{C}, \delta^{15} \mathrm{~N}\right)$ reveal associations among geographic location and condition of Alaskan Northern Pintails. Journal of Wildlife Management 72:715-725. http://dx.doi.org/10.2193/2007-115 